\title{
Unusual Proliferation of the Pancreatic Endocrine Cells in Adults, Suggestive of Islet Cell Metaplasia
}

\author{
Masanori HISAOKA and Akio HORIE \\ Department of Pathology and Oncology, School of Medicine, University of Occupational and \\ Environmental Health, Japan. Kitakyushu 807, Japan
}

\begin{abstract}
We present two adult autopsy cases with malignancy, in which unusual proliferation of the pancreatic endocrine cells was observed. Histopathological examination revealed extensive proliferation of the pancreatic endocrine cells throughout the pancreata in both cases. The islets of the pancreas were enlarged with irregular contours. An admixture of the islet cells, acinar cells and ductular epithelial cells was also observed. Immunohistochemically, these islets were composed of the endocrine cells of various types, i.e. A-, B-, D- and PP-cells, and they showed a predominance of PP-cells. Clinically, endocrine hyperfunction of the pancreas was not detected in either cases. Although this histological change may be described as endocrine cell hyperplasia or dysplasia, the close connection of the islet cells, acinar cells and ductular epithelial cells might rather suggest metaplastic change of the acinar or ductular cells into the islet cells under unknown stimuli.
\end{abstract}

Key words: pancreatic islet, hyperplasia, metaplasia, nesidioblastosis.

(Received 15 August 1990, accepted 17 September 1990)

\section{Introduction}

The proliferative changes of the pancreatic endocrine cells in adults are known to occur occasionally in association with several pancreatic diseases, i.e. chronic pancreatitis, diabetes mellitus, pancreatic endocrine cell tumors and cystic fibrosis (Bloodworth 1963; Brown \& Madge 1971; Dahms et al., 1976; Klöppel et al., 1978; Larsson 1977; Warren et al., 1966). Nesidioblastosis, proposed by Laidlaw (1938) as a diffuse or disseminated proliferation of the islet cells, has been found in several cases of infantile hyperinsulinemic hypoglycemia (Jaffe et al., 1980; Shermeta et al., 1980; Yakovac et al., 1971), and has the rather restricted meaning of endocrine hyperfunction. We recently encountered such a proliferative change of the islet cells in pancreata of two adult autopsy cases without any pancreatic disease or pancreatic endocrine hyperfunction.

We report these cases of such histological changes of the pancreatic endocrine cells with special reference to metaplasia.

\section{Case Report}

Case 1: A 59-year-old male had been suffering from bone pain of the scapula and 
pathological bone fracture of the 10th thoracic vertebra. After admission, he was diagnosed as having multiple myeloma by bone marrow aspiration biopsy, and chemotherapy was performed. In spite of the treatment, the tumor progressed and metastasized systemically, and finally he died of complicated severe interstitial pneumonitis at the interval of 7.5 years from the onset.

Case 2: A 60-year-old male, who was noted to have a suspicious shadow in the left upper lung by a routine roentgenogram of the chest, was referred to our hospital for further evaluation. A cytological examination of the sputa revealed squamous cell carcinoma of the lung and he underwent chemotherapy, radiation and hyperthermia. However, the treatment did not result in a favorable response and he died of respiratory failure caused by progression of the cancer after approximately 1.5 years from the time of detection of the malignancy.

Both cases had neither symptoms of hyperinsulinism nor of the other hyperfunctions of the pancreatic endocrine system. Laboratory studies on admission revealed fasting blood glucose levels of $114 \mathrm{mg} / \mathrm{dl}$ in case 1 'and $98 \mathrm{mg} / \mathrm{dl}$ in case 2, and diabetes mellitus (DM) was found only in case 1 later, who suffered from steroid-induced DM for a month (blood glucose; $464 \mathrm{mg} / \mathrm{dl}$ ). Plasma levels of insulin, glucagon, and other pancreatic hormones were not examined.

\section{Materials and Methods}

Obtained pancreata at autopsy were fixed in $20 \%$ formalin and serially divided into 28 and 35 tissue pieces at intervals of 5-10 $\mathrm{mm}$ thickness. All of them were embedded in paraffin, sliced into $4-6 \mu \mathrm{m}$ thick sections and were stained with hematoxylin-eosin (HE). In addition, sections from the head, body and tail of the pancreata were immunostained for insulin, glucagon, somatostatin, pancreatic polypeptide (PP), chromogranin A, neurospecific enolase (NSE), and gastrin, using the peroxidase-antiperoxidase (PAP) method and the avidin-biotin peroxidase complex $(\mathrm{ABC})$ method. Employed antihuman antibodies were purchased from DAKO-immunoglobulins Ltd., Denmark. Small pieces of formalin-fixed pancreatic tissues were re-fixed with $2.5 \%$ glutaraldehyde in $0.1 \mathrm{M}$ cacodylate buffer at pH7.4 following 2\% osmium tetroxide and embedded in Epok812. Ultrathin sections of them were double-stained with uranyl acetate and lead citrate, and examined with a JEM100CX electron microscopy.

For quantitative analysis of the endocrine tissue, the number of islets per $50 \mathrm{~mm}^{2}$ of the tissue area was counted and the ratio of the number of large islets over $250 \mu \mathrm{m}$ in diameter to the number of total islets was calculated. Control values for the study were obtained from other pancreatic tissue sections of 6 adult cases, which were selected randomly from recent adult autopsy cases in our hospital. 


\section{Results}

Microscopically, almost all the tissue sections disclosed many pancreatic islets, which were varied in size and had irregular contours (Fig. 1). Some of them were situated closely and larger than $500 \mu \mathrm{m}$ in diameter. The arrangement of the islet cells was mainly a gyriform pattern of cords. Each cord was in close contact with adjacent acinar cells, and the incorporation of acinar cells into the cords was also seen. Pancreatic ductules were involved in the islets or closely associated with them (Fig. 2). No apparent mitotic figures of the islet cells were observed. Focal goblet-cell hyperplasia of the ductular epithelium and mild interlobular fibrosis were found, however, well demarcated adenomatous lesions or hyalinized islets were not seen. Immunohistochemically, the islets were composed of four types of endocrine cells, i.e. A-, B-, D- and PP-cells, and PP-cells proliferated dominantly throughout the pancreata (Fig. 3). The islets were diffusely positive-stained for NSE and chromogranin A (Fig. 4), and were negatively stained for gastrin. Disseminated or isolated endocrine cells within the exocrine tissue were occasionally seen. Ultrastructurally, some acinar cells were in close contact with the endocrine cells at the periphery of the islet without demarcation with connective tissues (Fig. 5). Quantitative study of the pancreatic islets revealed a significantly increased number of islets per $50 \mathrm{~mm}^{2}$ and an increased proportion of large islets over $250 \mu \mathrm{m}$ in diameter (Table 1).

\section{Discussion}

Abundant reports and studies regarding hyperplastic or proliferative change of the pancreatic endocrine cells have been done. Usually this phenomenon is detected among infants with hyperinsulinemic hypoglycemia, and adult cases have been rarely found (Campbell et al., 1985; Keller et al., 1983; Weidenheim et al., 1983). In addition, some cases with other pancreatic diseases, i.e. chronic pancreatitis, diabetes mellitus, pancreatic endocrine cell tumors, and a few cases of extra-pancreatic diseases have been reported in association with such proliferation of the islet cells (Bloodworth 1963; Brown \& Madge 1971; Dahms et al., 1976; Hart \& Hinerman 1965; Klöppel et al., 1978; Larsson 1977; Warren et al., 1966). Laidlaw (1938) described a diffuse or disseminated proliferation of the islet cells as a possible cause of hypoglycemia and proposed the term "Nesidioblastosis". Therefore, nesidioblastosis has the rather restricted meaning of proliferation of the islet cells with insular hyperfunction. However, other terms such as, "Hyperplasia", "Dysplasia" "and "Adenomatosis" have been used with or without endocrine hyperfunction (Hart \& Hinerman 1965; Jacobs et al., 1986; Jaffe et al., 1980; Larsson 1977; Lloyd et al., 1981). Morphologically, it is difficult to distinguish each of them practically as they lack precise definitions. The etiology of the proliferation of the islet cells is still controversial. Some investigators have surmised genetic effect of persistence of embryonal development, whereas secondary change due to unknown stimuli has also been speculated on (Goudswaard et al., 1986; Hammersen 


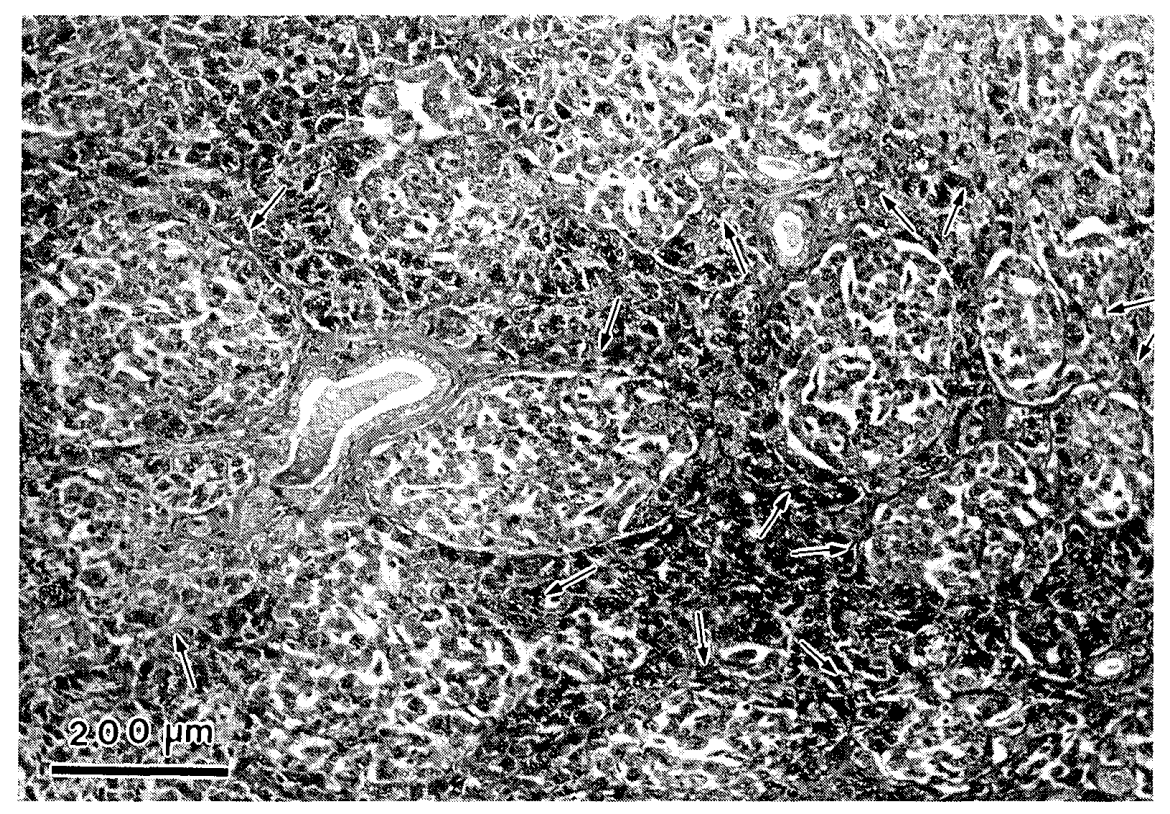

Fig. 1. Microscopic view of the tail of the pancreas in case 1 , showing numerous pancreatic islets closely situated (arrows). They consist of cords of the cells and are varied in size and shape. (H.E.).

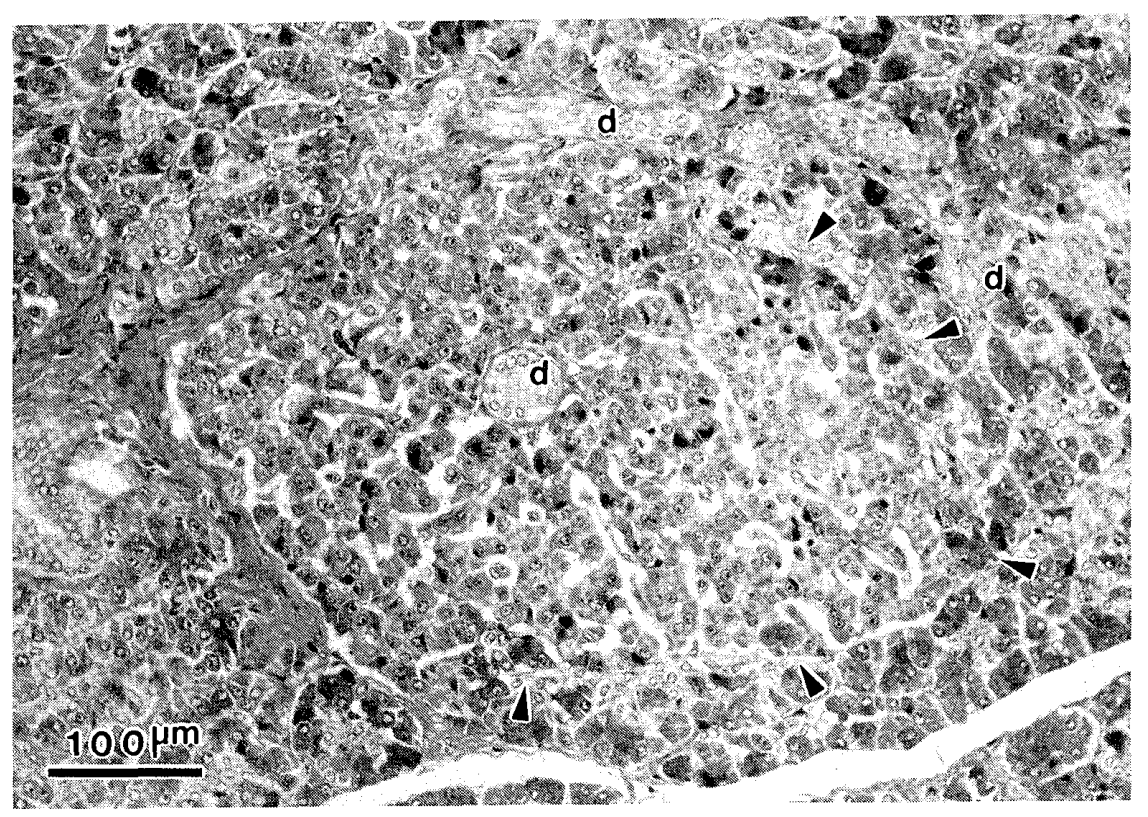

Fig. 2. High-power view of the body of the pancreas in case 2, showing a large pancreatic islet of over $500 \mu \mathrm{m}$ in diameter. Darkly stained acinar cells (arrowheads) and small pancreatic ductules (d) are in close contact with the islet cells. (H.E.).

et al., 1980; Heitz et al., 1977; Klöppel et al., 1978).

In the present cases, no endocrine hyperfunctions or pancreatic disorders were detected clinically. Histological examination showed an increased number and size of the islets with irregular contours, and the islets were composed of various types of the endocrine cells. 

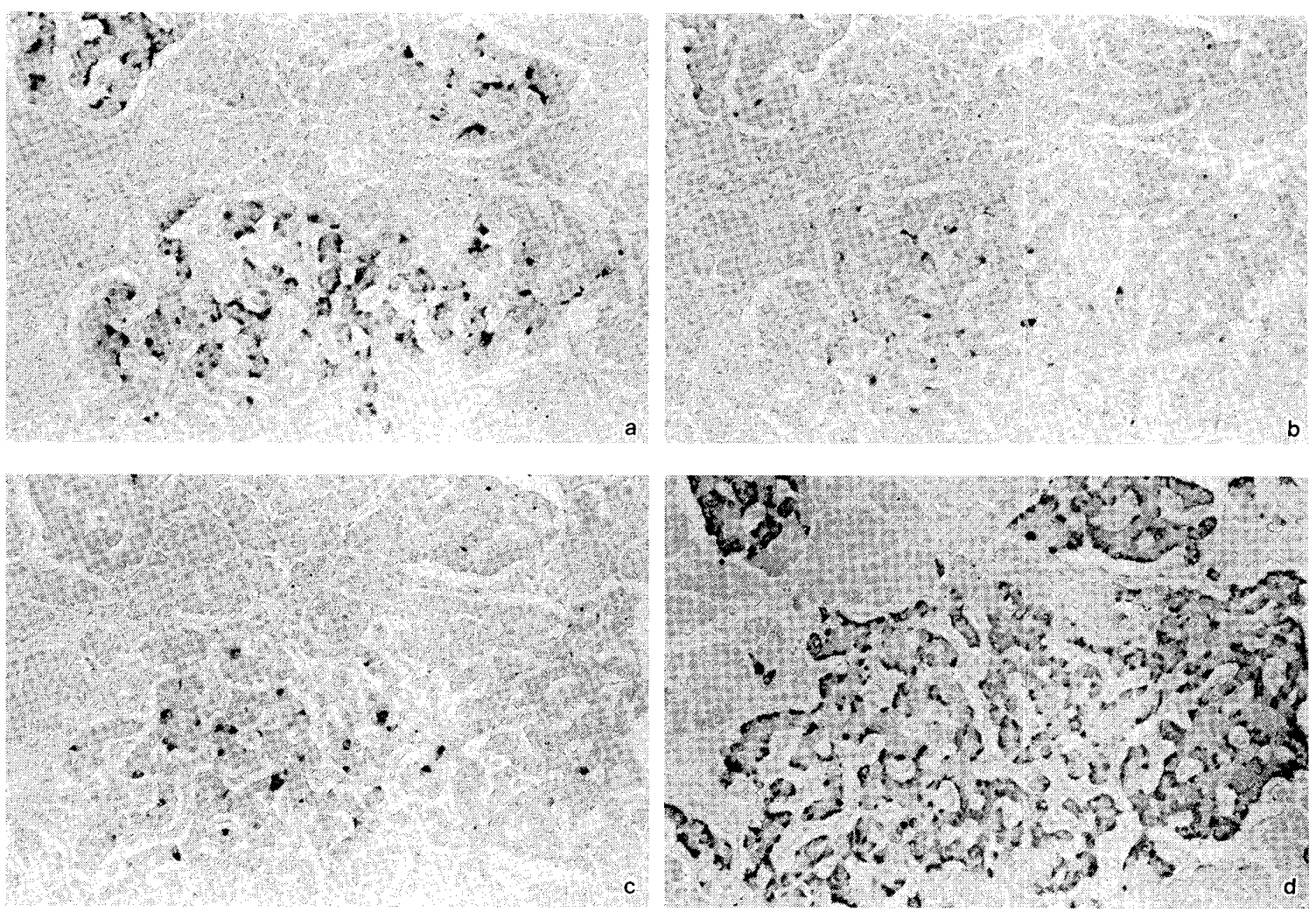

Fig. 3. Immunohistochemical stainings for insulin (a), glucagon (b), somatostatin (c) and pancreatic polypeptide (PP) (d) on serial tissue-sections of the pancreatic body in case $1 . \quad$ PP cells are stained predominantly. (Immunostaining with PAP method).

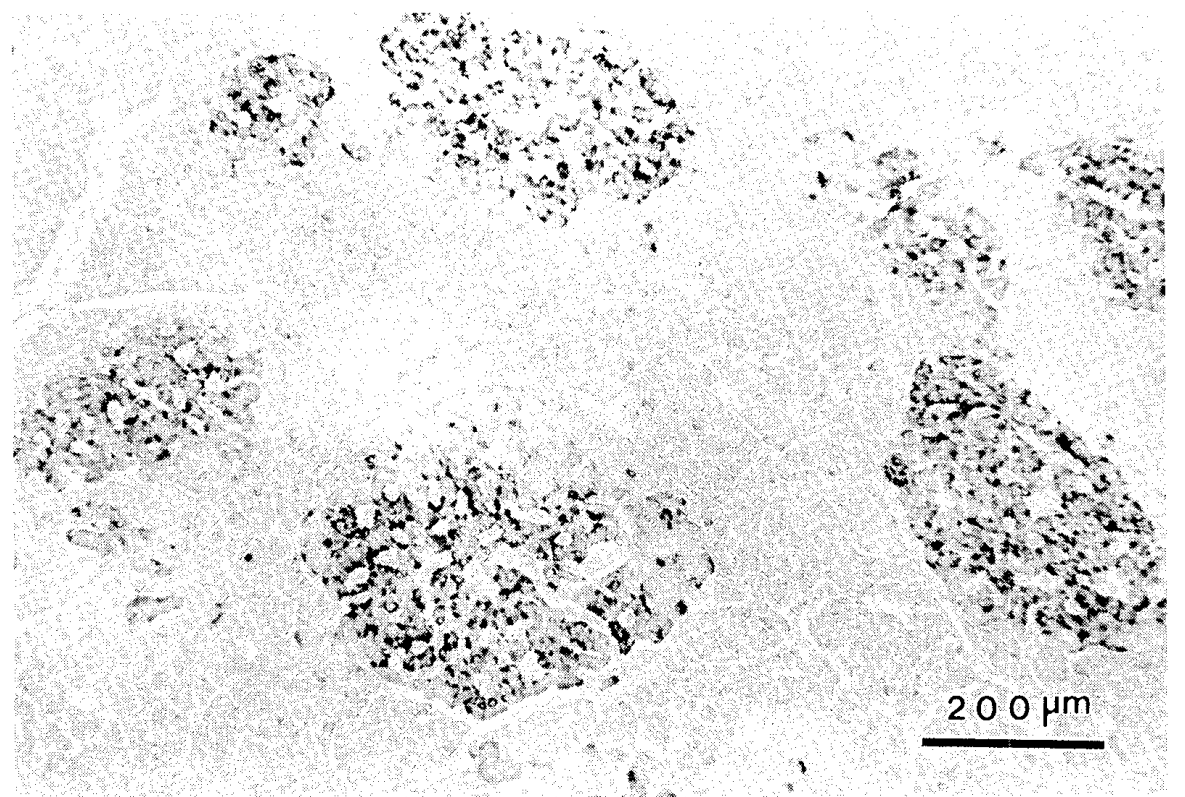

Fig. 4. Most of the islet cells are positively stained for chromogranin A. (Pancreatic tail in case 1 , immunostaining with $\mathrm{ABC}$ method). 


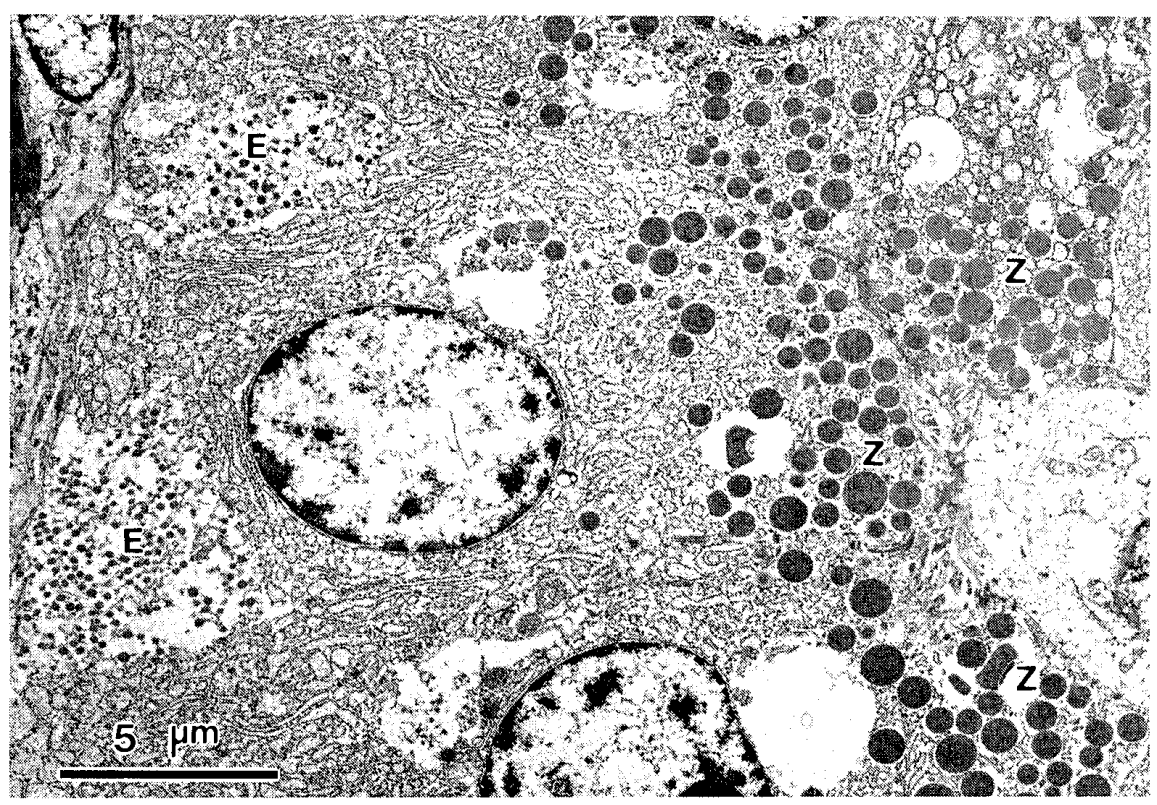

Fig. 5. Electronmicrograph of the peripheral part of the islet. Note admixture of two types of cells with numerous intracytoplasmic granules, i.e. the acinar cells with zymogen granules $(Z)$ and the islet cells with endocrine granules (E).

Table 1. Quantitative data of the pancreatic islets

\begin{tabular}{lcc}
\hline Case & $\begin{array}{c}\text { No. of islets } / 50 \mathrm{~mm}^{2} \\
(\text { Mean } \pm \mathrm{SD})\end{array}$ & $\begin{array}{c}\text { Percentage of large } \\
\text { islets }(\phi>250 \mu \mathrm{m})\end{array}$ \\
\hline 1 & $192.6 \pm 31.0$ & $8.67 \%$ \\
2 & $171.6 \pm 34.7$ & $8.20 \%$ \\
Cont. $(\mathrm{n}=6)$ & $120.2 \pm 34.3$ & $0.26 \%$ \\
\hline
\end{tabular}

Glose connection of the pancreatic islets, exocrine acini and ductules seemed to be an evidence of transformation of the ductular epithelial cells and acinar cells into the islet cells. Therefore, these changes also should be included in the category of "Metaplasia", defined as transformation of one form of differentiated tissue to another. Clinicopathological features of the present cases can be summarized as follows; 1) increased number and size of the pancreatic islets with irregular contours, 2) the islets closely associated with or incorporated in the pancreatic acini and ductules, 3) composition of various types of the endocrine cells, 4) practically no endocrine hyperfunctions, 5) changes occurred in adults with malignancy.

The reason for the discrepancy between the result of our immunohistochemical study and clinical findings of the two cases is unknown. We speculate that the produced hormones in proliferated islet cells may be immature and lacking in biological activities, or that the amount of hormones may not be enough to present any clinical symptoms, or that some disorders may exist in the secretory mechanism of hormones. 
The pancreatic islets and acini develop in the manner of branching or budding from the epithelium of the primitive pancreatic ducts during the fetal period. Some investigators have observed the transformation of the pancreatic exocrine cells into the endocrine ones (Leduc \& Jones 1968; Sétáló 1970), and the close connection of those cells have been also demonstrated (Bendayan 1982, 1987). Hence, the ductular epithelium and acinar cells might have the latent potential of transformation to the endocrine cells and some unknown stimuli might develop this potential after the full growth of the pancreas. The isolated or survived islets associated with atrophic pancreatic parenchyma, occasionally observed in chronic pancreatitis, suggest their resistance to chronic impairment of the pancreas. Therefore, chronic disorders of the exocrine system might cause such a transformation like squamous metaplasia of the uterine cervical mucosa associated with chronic cervicitis and that of the respiratory tract caused by habitual smoking. For example, hyperglycemia or high plasma levels of amino acids due to hyperalimentation, corticosteroids or other administrated medicines, and endogenous trophic factors have been considered possible stimuli of proliferative changes of the islet cells (Brown \& Young 1970; Weidenheim et al., 1983).

The significance of PP-cell predominance, observed in the present cases and previously reported by Larsson (1977), was obscure. Orci et al., (1978) found PP-rich lobules occasionally in the posterior portion of the pancreatic head which has been considered to correspond to the part of the pancreas derived from the ventral primordium. In our cases, however, PP-cells were localized predominantly even in the body and tail of the pancreas, and the PP-cell predominance might not always represent the developmental heterogenesis of the pancreas.

We propose that the etiology of the transformation process, including the elucidation of the stimuli and the role of PP-cells, should be examined in the future.

\section{References}

Bendayan, M. (1982): Contacts between endocrine and exocrine cells in the pancreas. Cell Tissue Res., 222: $227-230$.

Bendayan, M. (1987): Presence of endocrine cells in pancreatic ducts. Pancreas, 2: 393-397.

Bloodworth, J. M. B. Jr. (1963): Morphologic changes associated with sulfonylurea therapy. Metabolism, 12: $287-290$.

Brown, R. E. \& Madge, G. E. (1971): Cystic fibrosis and nesidioblastosis. Arch. Pathol. Lab. Med., 92: 53-57.

Brown, R. E. \& Young, R. B. (1970): A possible role for the exocrine pancreas in the pathogensis of neonatal leucine sensitive hypoglycemia. Am. J. Dig. Dis., 15: 65-72.

Campbell, I. L., Harrison, L. C., Ley, C. J. et al. (1985): Nesidioblastosis and multifocal pancreatic islet cell hyperplasia in an adult: Clinicopathologic features and in vitro pancreatic studies. Am. J. Clin. Pathol., 84: 534-541.

Dahms, B. B., Lippe, B. M., Dakake, C. et al. (1976): The occurrence in a neonate of a pancreatic adenoma 
with nesidioblastosis in the tumor. Am. J. Clin. Pathol., 65: 462-467.

Goudswaard, W. B., Houthoff, H. J., Koudstaal, J. et al. (1986): Nesidioblastosis and endocrine hyperplasia of the pancreas: A secondary phenomenon. Hum. Pathol., 17: 46-53.

Hammersen, G., Trefz, F. K. \& Schmidt, M. (1980): Familial nesidioblastosis. J. Pediatr., 96: 778.

Hart, W. R. \& Hinerman, D. L. (1965): Hyperplasia of pancreatic islets associated with extrapancreatic lymphoma and sarcoma. Metabolism, 14: 1158-1168.

Heitz, P. H. U., Klöppel, G., Hacki, W. H. et al. (1977): Nesidioblastosis; the pathologic basis for persistent hyperglycemia in infants. Diabetes, 26: 632-642.

Jacobs, D. G., Haka-lkse, K., Wesson, D. E. et al. (1986): Growth and development in patients operated on for islet cell dysplasia. J. Pediatr. Surg., 21: 1184-1189.

Jaffe, R., Hashida, Y. \& Yunis, E. J. (1980): Pancreatic pathology in hyperinsulinemic hypoglycemia of infancy. Lab. Invest., 42: 356-365.

Keller, A., Stone A. M., Valderrama, E. et al. (1983): Pancreatic nesidioblastosis in adults: Report of a patient with hyperinsulinemic hypoglycemia. Am. J. Surg., 145: 412-416.

Klöppel, -G., Bommer, G., Commandeur, G. el al. (1978): The endocrine pancreas in chronic pancreatitis. Immunocytochemical and ultrastructural studies. Virchows Arch. [Pathol. Anat.], 377: 157-174.

Laidlaw, G. F. (1938): Nesidioblastoma, the islet tumor of the pancreas. Am. J. Pathol., 14: 125-139.

Larsson, L. I. (1977): Two distinct types of islet abnormalities associated with endocrine pancreatic tumors. Virchows Arch. [Pathol. Anat.], 376: 209-219.

Leduc, E. H. \& Jones, E. E. (1968): Acinar-islet cell transformation in mouse pancreas. J. Ultrastruct. Res., 24: 165-169.

Lloyd, R. V., Caceres, V., Warner, T. F. C. S. et al. (1981): Islet cell adenomatosis. Arch. Pathol. Lab. Med., 105: 198-202.

Orci, L., Malaisse-Lagae, F., Baetens, D. et al. (1978): Pancretic-polypeptide rich regions in human pancreas. Lancet, 2: 1200-1201.

Sétáló, G. (1970): Light microscopic demonstration of acino-insular transformation. Acta Morph. Acad. Sci. Hung., 18: 359-367.

Shermeta, D. W., Mendelsohn, G. \& Haller, J. A. (1980): Hyperinsulinemic hypoglycemia of the neonate associated with persistent fetal histology and function of the pancreas. Ann. Surg., 191: 182-186.

Warren, S., Le Compte, P. M. \& Legg, M. A. (1966): The pathology of diabetes mellitus (4th ed). Lea \& Febiger, Philadelphia. p. 79.

Weidenheim, K. M., Hinchey, W. W. \& Campbell, W. G. Jr. (1983): Hyperinsulinemic hypoglycemia in adults with islet-cell hyperplasia and degeneration of exocrine cell of the pancreas. Am. J. Clin. Pathol., 79: 14-24.

Yakovac, W. C., Baker, L. \& Hummeler, K. (1971): Beta cell nesidioblastosis in idiopathic hypoglycemia of infancy. J. Pediatr., 79: 226-231. 
脺島細胞化生を示唆した成人における膵内分泌細胞の異常増生

久岡 正典・堀江 昭夫

産業医科大学第一病理学教室

要 旨： 2 体の成人悪性腫瘍剖検症例の膵に, 奇異な内分泌細胞増殖像が認められたので報告する. 組織学的に，2 症例とも膵全体にわたって著明な膵島の増生像が見られ，膵島は大型で辺 縁は不規則であった。また，膵島細胞，腺房細胞，膵管上皮細胞の混在した像も見られた。 免疫組織化学的に，膵島は種々の内分泌細胞，すなわち A, B, D, PP 細胞から構成されて 拐り，特に，PP 細胞の優位性が認められた。臨床的には 2 症例とも明らかな膵内分泌機 能の克進を認められてはいなかった。このような膵島の組織学的変化は内分泌細胞過形成 あるいは異形成と表現されるのであろうが，膵島細胞と腺房細胞，膵管上皮細胞との密接 な関係からは，むしろ何らかの刺激によるこれら細胞の膵島細胞への化生性变化が示唆さ れた。

J. UOEH（産業医大誌）, 12(4): 429-437 (1990) 